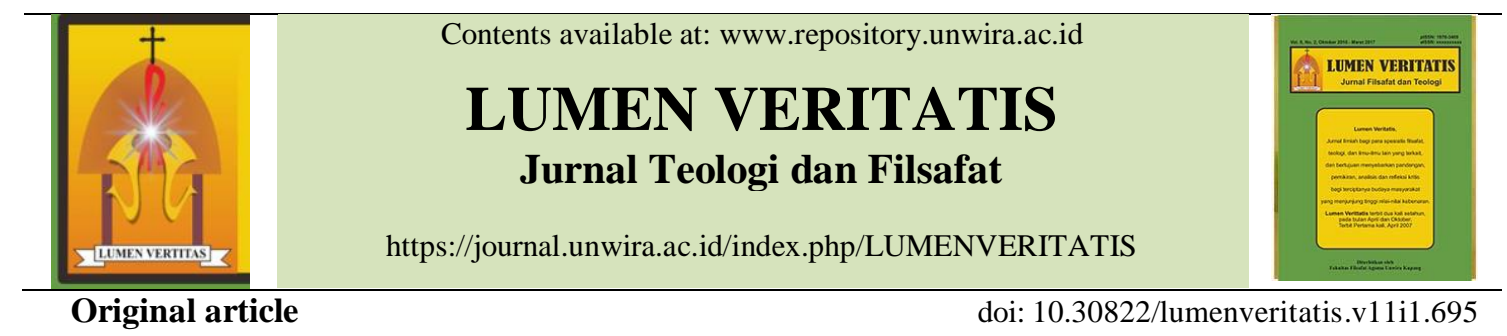

\title{
TUHAN ITU PENUH KASIH DAN HUKUM-HUKUMNYA MENGHIDUPKAN
}

\author{
Mikhael Valens Boy*, Siprianus S. Senda \\ Magister dalam Bidang Kitab Suci, Program Studi Ilmu Filsafat, Fakultas Filsafat, \\ Universitas Katolik Widya Mandira Kupang \\ *Email: valensboy239@gmail.com
}

\begin{abstract}
Underscrutinized psalms of 93,100,121,126 and 128 are underlaying and performing the very essence of the God of Israel as the merciful, loving and liberating God. Nothing is to lose with the God of Israel. The essence of the God of Israel as the eternal King (Ps.93), the faithful Keepguarder (Ps. 121) and the Hope of Israel (126) provokes and invites the people of Israel to hail and to adore Him in His Holy Place (Ps. 100) in order to get and to inherit His plentiful Blessings (Ps. 128). In other words, those who have the holy fear to God and faithfully obeying His commandments deserve God's blessings. On these theological perspectives we have investigated the Catholic parishioners and its leaders of St. Peter and Paul's half Parish - Oesapa, to find out howfar they have performed and embodied the mercy of God and obeying His commandments. And they are making effort and advancing in serving the Church and obeying the God's commandments.
\end{abstract}

Keywords: God of Israel, Eternal King, Faithful Keepguarder, Hope, Holy Place, Blessings, Mercy, Commandments, to hail, to adore, to obey, the Church, St. Peter and Paul-Oesapa

\section{Pendahuluan}

Tuhan dalam Dirinya Sendiri adalah kasih yang sempurna dan tak terbatas. Kehendak-Nya dan perbuatan-perbuatanNya dijalankan semata-mata berdasarkan kasihNya yang abadi dan tak tertandingi. Tuhan telah menciptakan manusia dengan kelengkapan akal budi dan kehendak bebas, supaya manusia dapat mengambil bagian dalam kehidupan-Nya yang ilahi dan bahagia. ${ }^{1}$ Hakekat hakiki dari Tuhan dapat ditemukan dalam Surat Rasul Yohanes: Ho Theos Agape Estin, yaitu "Allah adalah Kasih" (Yoh. 4:8.16). Deus Caritas Est.

1 Paus Yohanes Paulus II (Promulgator), Katekismus Gereja Katolik, terjemahan
Bangsa Israel yang secara kuantitatif sedikit jumlahnya, sungguh besar dalam keimanan monotheisme. Kitab-Kitab Suci bangsa Ibrani yang terkategori dalam Torah, Nebiim dan Ketubim mengungkapkan betapa bangsa ini sejak dahulu terus berada dalam 'perjanjian' dengan Tuhan. Kitab-Kitab ini mengungkapkan bahwa melalui PerjanjianNya, Tuhan, Allah Israel menampakkan kasih setiaNya yang besar dan agung bagi bangsa Israel. Formasi Bapak-Bapak Bangsa dan Pembebasan Israel dari Perbudakan Mesir oleh Tuhan, menunjukkan bahwa Tuhan sungguh

Indonesia P. Herman Embuiru, SVD, (Ende: Propinsi Gerejani Ende, 1995), No. 1. 
penuh kasih kepada Israel. Akan tetapi, Perjanjian Tuhan dengan Israel juga mempunyai implikasi hukum sebagaimana direpresentasikan dalam keprihatinan teologis dari Kitab-Kitab Sejarah Deutronomium, yaitu bahwa Israel yang taat kepada Hukum Tuhan, akan selamat, dan Israel yang menolak dan tidak taat kepada Hukum Tuhan, akan binasa. Pembuangan-pembuangan Israel ke Asyur dan kemudian Yehuda ke Babilonia menampakkan kegagalankegagalan Israel dalam menjawabi kasih setia Tuhan dengan berlaku tidak taat kepada hukum-hukum Tuhan. Padahal Hukum Tuhan itu menghidupkan: "Taurat TUHAN itu sempurna, menyegarkan jiwa; peraturan TUHAN itu teguh, memberikan hikmat kepada orang yang tak berpengalaman. Titah TUHAN itu tepat, menyukakan hati; perintah TUHAN itu murni, membuat mata bercahaya. Takut akan TUHAN itu suci, tetap ada untuk selamanya; hukumhukum TUHAN itu benar, dan adil semuanya, lebih indah dari pada emas, bahkan dari pada emas tua; dan lebih manis dari pada madu, bahkan dari pada madu tetesan" (Mzm 19:8-11).

Kitab Mazmur yang adalah bagian dari Kitab Ketubim merupakan 'madah' iman Israel akan kebesaran dan keagungan kasih setia Tuhan bagi mereka sepanjang sejarahnya. Kitab Mazmur berhakekat sebagai nyanyian pujian, doa dan syair agung yang menyatakan iman dan kepercayaan umat Israel kepada Allah. Dalam Kitab ini, bangsa Israel mengungkapkan perasaan-perasaannya seperti dukacita dan sukacita, keraguan dan kepercayaan, hati yang terluka dan

${ }^{2}$ Lembaga Alkitab Indonesia, "ELOHIM", dalam ALKITAB Edisi Studi, (Jakarta: Lembaga Alkitab Indonesia, 2011), hlm. 867 terhibur, keputusasaan dan pengharapan, kemarahan dan ketenangan, keinginan balas dendam dan mengampuni. Prinsipnya di dalam Mazmur-Mazmur Israel 'berbagi perasaan' dengan Allah dan percaya bahwa Tuhan 'akan' menjawabi doa-doa mereka, karena mereka mengimani sungguh bahwa Tuhan adalah Pencipta dan Penyelamat mereka. $^{2}$ Di dalam Mazmur-Mazmur dipesankan pula bahwa kasih karunia Tuhan bagi Israel mengejahwantah juga di dalam ketaatan Israel terhadap hukumhukum Tuhan. Dan bahwa Tuhan berkarya dan menyelamatkan bangsa Israel melalui pengaplikasian hukum Tuhan di dalam tingkah laku hidup mereka sehari-hari.

Mazmur 93, 100, 121, 126, dan 128 yang adalah landasan teoritis dari penelitian kami dapat menjadi acuan bagi orang Kristen dalam membina kehidupan imannya. Mazmur-Mazmur aslinya mengekspresikan 'iman', yaitu sikap takut akan Tuhan dari bangsa Israel yang menjadi landasan ketaatan Israel terhadap hukum-hukum Tuhan. Pada gilirannya, sikap takut akan Tuhan yang dihadirkan dalam Mazmur-Mazmur dapat menjadi roh dan jiwa umat Kristiani dalam menghayati 'hukum-hukum Tuhan' dalam kehidupan menggereja. Demikian, berdasarkan hubungan tradisional 'yudeo-kristiani', maka sikap takut akan Tuhan bangsa Israel dapat menjadi roh dan jiwa dari karya kerasulan dan pelayanan manusia kristiani. 
Tuhan itu penuh kasih dan hukumhukumnya menghidupkan

\section{a. Tuhan adalah Raja yang kekal}

Mazmur 93 adalah sebuah madah agung kepada Tuhan sebagai Raja atas kemenanganNya terhadap kekuatankekuatan yang menghancurkan dari khaos, dan atas kekuasaan Tuhan yang menjadi fondasi tegaknya bumi ini. $^{3}$ Tuhan, Allah Israel adalah Raja yang menjadi prinsip 'tegaknya' kosmos dan kehidupan manusia. Di dalam segala hal dan pada semua zaman, Tuhan merupakan prinsip kebaikan dan prinsip keselamatan. Mazmur 93 membentuk satu inklusio kekuasaan dan kekuatan Tuhan. Ada hubungan yang erat antara Tuhan sebagai Raja yang kekal dengan keteguhan peraturanNya. Dengan kata lain, karena Tuhan itu Raja yang kekal, maka peraturanNya teguh dan konstruktif. Hubungan inklusif antara hakekat Tuhan sebagai Raja yang kekal dengan peraturanNya yang teguh dapat ditemukan di dalam 'pasangan' ayat-ayat ini: "TUHAN adalah Raja, Ia berpakaian kemegahan, TUHAN berpakaian, berikat pinggang kekuatan. Sungguh, telah tegak dunia, tidak bergoyang; takhtaMu tegak sejak dahulu kala, dari kekal Engkau ada" (ay. 1-2) 'berpasangan' dengan "PeraturanMu sangat teguh; baitMu layak kudus, ya TUHAN, untuk sepanjang masa" (ay. 5). Hukum-hukum Tuhan yang menghidupkan bersumber pada hakekat Tuhan sebagai Raja, dan Raja yang kekal. Kekekalan kekuasaan Tuhan berbasis pada hakekat Tuhan yang ilahi, yang transenden, dan yang berpreeksistensi.

\footnotetext{
${ }^{3}$ L. Alonso Schoekel, I SALMI 2, (Roma: Borla, 1993), p. 299
}

Hakekat Tuhan sebagai Raja yang kekal dan yang berpreeksistensi terungkap dalam pernyataan-pernyataan ini, "takhtaMu tegak sejak dahulu kala, dan dari kekal Engkau ada", dan "lebih hebat TUHAN di tempat tinggi". Kedua pernyataan ini menjadi jaminan dan kekuatan dari "sungguh, telah tegak dunia, tidak bergoyang" dan "peraturanMu sangat teguh; baitMu layak kudus". Hakekat dan kekuasaan Tuhan sebagai Raja yang kekal 'menurunkan dan mengalirkan' hukum-hukumNya yang sejati, yang sangat bermanfaat bagi keselamatan manusia dan dunia. Kekuatan-kekuatan gelap dan jahat, ketidakteraturan dan kerusakan kehendak dan akal budi manusia, kekhaosan filosofis dan teologis dari orang-orang jahat sebagaimana disimbolkan dalam "sungai-sungai telah mengangkat suaranya, mengangkat bunyi hempasannya. Dari pada suara air yang besar, dari pada pecahan ombak laut yang hebat", tidak akan dapat menggagalkan hukum-hukum Tuhan, karena "lebih hebat TUHAN di tempat tinggi". 'Sungai' dan 'laut' adalah lambang kuasa kekacauan, khaos. ${ }^{4}$

\section{b. Kasih setia Tuhan meruapakn alasan mendasar dari puji-sembah manusia kepada Allah}

Mazmur 100 merupakan sebuah madah pujian kepada Tuhan karena kebaikan dan kasih setiaNya. "Kebaikan dan kasih setia Tuhan untuk selamalamanya" menjadi alasan mendasar mengapa manusia harus memuji dan memuliakan Tuhan dengan beribadat kepadaNya. Kebaikan dan kesetiaan Tuhan yang bersifat kekal untuk selama-

\footnotetext{
${ }^{4}$ Lembaga Alkitab Indonesia, "ELOHIM", $\boldsymbol{O} \boldsymbol{p}$. Cit., hlm. 957
} 
lamanya menjadi prinsip dan motivasi bagi manusia beriman untuk tekun beribadat kepadaNya. Rumusan "TUHAN itu baik, kasih setiaNya untuk selama-lamanya, dan kesetiaanNya tetap turun temurun' (ay. 5) merupakan prinsip paling mendasar dan motivasi paling penting dari penyerahan diri dan kepercayaan manusia kepada kehendak Allah yang menyelamatkan. ${ }^{5}$

Kebaikan dan kasih setia Tuhan kepada manusia dimanifestasikan Tuhan kepada kita dalam peristiwa penciptaan manusia. Penciptaan eksistensi manusia saja sudah merupakan sebuah hadiah gratis Tuhan kepada manusia. Apalagi eksistensi manusia 'kemudian' dilengkapi dengan hadiah istimewa esensi manusia sebagai citra Allah. Kodrat manusia sebagai animal rationale merupakan kekhasan dan keistimewaan manusia demi hidup dan keselamatannya: "Ketahuilah, bahwa TUHANlah Allah; Dialah yang menjadikan kita dan punya Dialah kita" (ay. 3a). Kodrat manusia yang demikian ini memampukan manusia untuk menjawabi kebaikan dan kasih setia Tuhan dengan berlaku menurut hukum dan ketetapan Tuhan. Dengan menggunakan otak untuk berpengetahuan yang benar dan kehendak untuk mentaati perintah Tuhan, manusia berakses kepada keselamatan abadi.

Kepemilikan Tuhan terhadap manusia dan hidupnya tidak hanya bersifat eksistensial dan esensil, tetapi juga bersifat 'eklesiastik'. Bukan saja "Dialah yang menjadikan kita dan punya Dialah kita" (ay. 3a), akan tetapi modus persatuan kita dengan Tuhan adalah bahwa kita ini "umatNya dan kawanan domba gembalaanNya" (ay. 3b). Hidup

\footnotetext{
${ }^{5}$ L. Alonso Schoekel, Op. Cit., p. 368
}

manusia beriman terikat dengan perjanjian dengan Tuhan, di mana manusia beriman berada di bawah komando dan tuntunan kepemimpinan Tuhan. Tuhan memimpin kesatuan kita dengan menerapkan hukum-hukum dan ketetapan-ketetapanNya untuk ditaati manusia. Persekutuan manusia beriman membentuk satu 'gereja' yang bertuankan Tuhan. Dalam hal ini Tuhan merupakan Raja yang kekal dan Dialah yang memimpin seluruh keberadaan dan dinamika hidup kita.

Yang juga khas dalam Mazmur 100 yakni bahwa locus manifestasi keberimanan dan ketaatan kita kepada Tuhan dan hukum-hukumNya adalah 'BaitNya yang suci': "Masuklah melalui pintu gerbangNya dengan nyanyian syukur, ke dalam pelataranNya dengan puji-pujian" (ay. 4a). Bait suci sebagai locus kehadiran Allah mengundang kita umat Tuhan untuk dengan gembira dan penuh sukacita datang dan sujud menyembah Dia. Sujud dan sembah kita secara liturgis menjadi nafas dan tenaga manusia beriman untuk dapat mengimplementasikan hukum-hukum dan ketetapan-ketetapan Tuhan di dalam keseharian hidupnya. Demikian dari BaitNya yang suci mengalirlah rahmat demi rahmat dan kasih setia demi kasih setia.

$\begin{array}{lcr}\text { c. Tuhan adalah Penjaga Yang Setia } \\ \text { Mazmur } 121 \text { adalah Mazmur } \\ \text { Kepercayaan, dan Mazmur ini } \\ \text { mengundang } & \text { manusia } & \text { kepada }\end{array}$ kepercayaan. ${ }^{6}$ Tese dari semua Mazmur Kepercayaan adalah bahwa 'hanya di dalam Tuhan, jiwaku tenang'. Manusia peziarah mempercayakan hidup dan karyanya dalam pemeliharaan Tuhan.

${ }^{6}$ Ibid., 634 
Manusia peziarah menggantungkan hidupnya kepada pemeliharaan Tuhan karena memang Dialah penjaga yang paling setia: "Pertolonganku ialah dari TUHAN, yang menjadikan langit dan bumi" (ay. 2). Sebagai Pencipta langit dan bumi, pemeliharaan Tuhan bersifat komprehensif dan tak terkalahkan. Tuhan merupakan pemelihara yang 'berkuasa dan berdaulat' karena Dialah Pencipta dan dengan demikian Dia pulalah Penyelamat. Hanya kepada Tuhan yang demikian sajalah manusia perlu mempercayakan hidupnya. Pemelihara tanpa 'kekuasaan dan kedaulatan' sebagai Pencipta tidak berada dalam posisi sebagai Penyelamat.

Kualitas pemeliharaan Tuhan terhadap manusia yang bersifat utuh dan penuh kesetiaan dinyatakan juga dalam Mazmur ini: "Ia tidak akan membiarkan kakimu goyah, Penjagamu tidak akan terlelap. Sesungguhnya tidak terlelap dan tidak tertidur Penjaga Israel" (ay. 3-4). Hanya Tuhanlah yang mempunyai kemampuan dan ketenagaan yang demikian sempurna dalam memelihara hidup manusia. Mengapa kualitas kesempurnaan penyelenggaraan dan pemeliharaan hanya ada pada Tuhan? Kembali kita menemukan di sini 'keadaan' Tuhan sebagai Pencipta Alam Semesta, yaitu kodrat keilahian dan keabadianNya sebagai dasar dan landasan keutuhan dan kesempurnaan pemeliharaan dan kewaspadaanNya: "Pertolonganku ialah dari TUHAN, yang menjadikan langit dan bumi" (ay. 2).

Eksistensi dan esensi Tuhan sebagai Pencipta Alam Semesta merupakan dasar dan landasan kesempurnaan Tuhan dalam memelihara eksistensi dan esensi manusia. Pemeliharaan Tuhan tidak hanya sampai kepada level, "Ia takkan membiarkan kakimu goyah, Penjagamu tidak akan terlelap" (ay. 3), tetapi "TUHAN akan menjaga engkau terhadap segala kecelakaan; Ia akan menjaga nyawamu" (ay.7). Pemeliharaan Tuhan kepada manusia sangat bersifat eksistensial bagi manusia. Atau Tuhan atau 'kematian'. Tidak ada opsi lain selain Tuhan sebagai satu-satunya pemelihara mutlak dari manusia. Kekekalan Tuhan sebagai Pencipta dan Penyelamat merupakan landasan ketaktergantikan dan kemutlakan dari pemeliharaan manusia: "TUHAN akan menjaga keluar masukmu, dari sekarang sampai selama-lamanya" (ay. 8).

\section{d. Tuhan merupakan Pengharapan manusia di tengah-tengah penderitaan}

Mazmur 126 merupakan Mazmur Syukur karena adanya restorasi, dan serentak merupakan pula satu Mazmur Permohonan agar restorasi ini mencapai kepenuhannya. Mazmur ini menghadirkan syukur, kegembiraan dan sukacita Israel karena Tuhan berkenan memulihkan dan merestorasi Sion. ${ }^{7}$ Mazmur ini berkontekskan situasi pembuangan Israel ke Babilon oleh raja Nebukadnezar pada tahun 586/587 SM. Mulanya Nebukadnezar mengalahkan Yehuda dan menghancurkan Bait Allah. Segala barang-barang suci milik Bait Allah dan semua pemuka Israel, raja, bangsawan digiring ke pembuangan di Babilon. Akan tetapi yang tidak tersangkakan bahwa baru saja empat puluh tahun di pembuangan, raja Median, Koresy mendekritkan pembebasan dan pemulangan Israel. Orang-orang Israel yang dibuang diizinkan kembali ke Sion.

${ }^{7}$ Ibid. 
Dan di sini pemazmur memandang kembalinya Israel dari pembuangan di Babel dan pembangunan kembali Yerusalem sebagai mukjizat dan karya agung Allah. Begitu juga, orang Israel berbicara tentang keluarnya mereka dari perbudakan Mesir dan penyeberangan yang aman di Laut Merah sebagai perbuatan ajaib Allah bagi mereka. ${ }^{8}$

Fantastik dan tak terkirakan "seperti memulihkan batang air kering di Tanah Negeb" (ay.4)! "Ketika TUHAN memulihkan keadaan Sion, keadaan kita seperti orang bermimpi" (ay.1). Tidak terbayangkan sukacita Israel atas keadaan ini: "Pada waktu itu mulut kita penuh dengan tertawa, dan lidah kita dengan sorak-sorai” (ay.2a). Di Tanah Negeb, pada musim hujan, batang air yang kering secara tiba-tiba dapat menjadi aliran air. Ini merupakan kejadian yang indah dan ajaib terutama Karena terjadi di padang gurun. Kembalinya Israel dari Pembuangan di Babel bagi Israel sungguh merupakan satu 'Keluaran Baru'. Dan karena itu Israel berani mempunyai Visi Baru: "Orang-orang yang menabur dengan mencucurkan air mata, akan menuai dengan bersoraksorai. Orang yang berjalan maju dengan menangis sambil menabur benih, pasti pulang dengan sorak-sorai sambil membawa berkas-berkasnya" (ay. 5-6). Di sini, tangisan umat Israel menunjukkan betapa dalamnya kesusahan mereka, Namun, mereka berdoa, memohon dan mengharapkan tuaian yang penuh sukacita. Keyakinan umat Israel pada saat menderita ini menyatakan bahwa umat Allah selalu hidup dalam penantian yang berpengharapan. ${ }^{9}$
Yang menjadi pertanyaan adalah mengapa Israel yang adalah bangsa pilihan Allah dibuang ke Babilon? Mengapa Tuhan sampai hati membiarkan bangsa pilihanNya dikalahkan oleh Nebukadnezar, Bait Allah hancur, dan pemimpin-pemimpin Israel digiring ke pembuangan? Mengapa Israel mengalami penghukuman Tuhan? Jawabannya adalah sebagaimana yang dicetuskan oleh teologi Kitab-Kitab Sejarah, yaitu karena Israel telah tidak berlaku taat kepada Tuhan. Ketidaktaatan dan ketidaksetiaan Israel kepada kehendak dan hukum-hukum Tuhan mendatangkan malapetaka bagi dirinya. Berpalingnya Israel dari Tuhan kepada dewa-dewa asing membawa penghukuman Tuhan bagi Israel. Dalam peristiwa pembuangan, Tuhan sesungguhnya menghukum Israel dengan menggunakan tangan bangsa asing.

Pertanyaan lain lagi, yakni mengapa di tengah-tengah penderitaan kita manusia urgen berharap pada Tuhan? Kembali kita menemukan teologi Sejarah Deutronomium menjawab, bahwa kasih setia Tuhan yang tidak berubah dan kesetiaan Tuhan kepada janji-janjiNya sejak Abraham merupakan landasan mengapa di tengah-tengah penderitaan Israel tetap berharap kepada Tuhan. Tuhan melakukan sesuatu berdasarkan kasihNya yang tidak terbatas. Bila Tuhan menghukum, Ia toh memulihkan. Bila Tuhan melukai, Ia toh menyembuhkan. Peristiwa ajaib Tuhan mengembalikan Israel secara fantastik dari pembuangan di Babilon, mengajarkan Israel untuk di dalam segala situasi, juga yang paling terpuruk, harus tetap berharap dan

\footnotetext{
${ }^{8}$ Lembaga Alkitab Indonesia, "ELOHIM", op. $\quad{ }^{9}$ Ibid. Cit., 990
} 
mempercayakan hidupnya kepada penyelenggaraan Tuhan.

\section{e. Tuhan adalah Pemberi berkat atas 'rumah tangga'}

Mazmur 128 dibuka dengan ucapan: "Berbahagialah setiap orang yang takut akan TUHAN, yang hidup menurut jalan yang ditunjukkanNya" (ay.1). Kata pembukaan "berbahagialah" menunjukkan bahwa Mazmur ini adalah Satu Ucapan Bahagia dan karena itu serentak merupakan pula satu Mazmur Kebijaksanaan. ${ }^{10}$ Mazmur ini berpesan bahwa berkat Tuhan disediakan bagi "setiap orang yang takut akan TUHAN, yang hidup menurut jalan yang ditunjukkanNya", yaitu orang-orang yang mentaati Tuhan dan menghormati hukumNya. Berkat itu mencakup pula panen yang berhasil dan banyak anak yang sehat: "Engkau akan memakan hasil jerih payah tanganmu, ... Istrimu akan menjadi seperti pohon anggur yang subur di dalam rumahmu; anak-anakmu seperti tunas pohon zaitun sekeliling mejamu" (ay. 2-3).

Tuhan memang menjanjikan keadaan akan baik, tetapi tidak berarti mereka yang taat kepada Allah dan hukum-hukumNya tidak akan mendapat kesukaran. Terjadi bahwa orang-orang benar seperti Abraham, Ishak, Yakub, Ayub dan para nabi justru mendapat banyak tantangan dan kesukaran. Kesehatan, kekayaan, kemakmuran, kesuburan dan kesuksesan dapat menjadi bukti penyertaan Tuhan. Akan tetapi, penderitaan, penyakit, musibah, kecelakaan, kemiskinan dan keterbuangan tidak membatalkan penyertaan Tuhan yang bersifat tetap dan abadi.
Ayat 5 dan 6 dari Mazmur 128 menyatakan bahwa semua berkat Tuhan bersumber dari Sion, karena di sanalah Bait Allah TUHAN berada: "Kiranya TUHAN memberkati engkau dari Sion... Damai sejahtera atas Israel". Sion sebagai sumber berkat karena keberadaan Tuhan di BaitNya yang suci menunjukkan kepada Israel khususnya bahwa kekudusan Tuhan adalah dasar segala rahmat. Dan karena Tuhan itu kudus, maka Israel pun harus menjadi bangsa yang kudus. Kekudusan manusia hanya terjadi bila manusia hidup menurut kehendak Allah dan taat kepada hukumhukumNya. Bahwa, tidak ada keselamatan di luar ketaatan kepada Tuhan dan perintah-perintahNya.

\section{Bakal Paroki Oesapa berdinamika dalam ketaatan kepada hukum- hukum Tuhan}

\section{a. Situasi umum bakal Paroki St. Petrus dan Paulus Oesapa}

Gereja St. Petrus dan Paulus Oesapa merupakan salah satu Bakal Paroki dalam Keuskupan Agung Kupang yang berada di wilayah kota Kupang. Batas teritorial Kuasi Paroki Oesapa: Utaranya berbatasan dengan pantai Oesapa di Teluk mulut Pulau Timor; Selatannya berbatasan dengan Paroki Penfui, dan tepatnya Stasi YMY (Yesus Maria Yosef); Timurnya berbatasan dengan Bakal Paroki St. Andreas Lasiana, dan Baratnya berbatasan dengan Stasi Kelapa Lima dari Paroki Kristus Raja Kupang. Luas teritorial dari Bakal Paroki sekitar 4 $\mathrm{km}$ persegi $(2 \mathrm{X} 2 \mathrm{~km})$. Topografi tanahnya berimbang antara dataran dan ketinggian. Permukaan tanahnya umumnya dipenuhi dengan karang dan cadas, dan karena itu agak gersang. Flora

${ }^{10}$ Ibid., hlm. 686 
aslinya kurang bervariasi, sebagiannya ditumbuhi lontar dan sebagiannya semak belukar dan pohon-pohon biduri. Udaranya, kering, panas dan berangin. Seperti wilayah kota Kupang pada umumnya, sedikit musim hujan, dan berkepanjangan musim panasnya sampai $8-9$ bulan per tahun.

Gereja St. Petrus dan Paulus Oesapa menjadi Bakal Paroki pada tahun 2015. Sebelumnya merupakan salah satu Stasi dari Paroki St. Yosep Pekerja Penfui. Jumlah Umat Katolik sebanyak 310 kepala keluarga (sekitar 1700-an jiwa) yang terdiri dari umat dewasa: 600-an orang, pemuda: 900-an orang dan anakanak: 200-an orang. Sebagian besar komposisi umat didominasi oleh pemuda dan pemudi, dan kebanyakannya adalah mahasiswa-mahasisiwi. Banyak sekali mahasiswa-mahasiswi ini tinggal di koskos dan rumah-rumah kontrakan yang tersebar di antara perumahan penduduk. Pemilik kos-kos dan rumah-rumah kontrakan ini tidak semuanya beragama Katholik, Banyak pula yang beragama Protestan dari berbagai denominasi. Salah satu karakter umum dari Bakal Paroki Oesapa ini adalah tersebarnya penduduk beragama Katholik di antara saudara-saudara Kristen Protestan dan Islam.

Pada awalnya berdirinya, Bakal Paroki St. Petrus dan Paulus Oesapa terorganisir dalam 8 KUB. Tetapi, dengan bertambahnya jumlah umat Katolik terjadilah pemekaran menjadi 13 KUB dan 5 Wilayah Gerejani. Secara etnis umat Katholik di Bakal Paroki ini berasal dari berbagai latar belakang etnis: Timor, Flores, Sabu, Rote, Sumba, Alor, Jawa, Toraja, dan lain-lain. Mata pencarian umat di Gereja ini bervariasi: Banyak yang bekerja sebagai sopir, nelayan, tukang bangunan, pedagang kaki lima, karyawan/i di toko. Sebagian kecil dari umat bekerja sebagai ASN/ PNS, wiraswastawan dan pensiunan PNS. Karena kebanyakan umat bermata pencaharian sebagai nelayan, buruh dan pedagang kaki lima, maka ditinjau dari segi ekonomi, banyak umat di Bakal Paroki in berpenghasilan lemah, tidak menentu, dan 'morat-marit'. Kemiskinan ekonomi merupakan salah satu kharakter dari sebagian umat Oesapa.

Penghasilan ekonomi yang lemah dan pola hidup kos-kosan dan kontrakan pada sebagian umat Katolik Oesapa berdampak bagi kehidupan rohani mereka. Banyak umat yang lemah visi imannya karena mereka 'kelelahan' mencari nafkah. Fenomena perkawinan campur dan pergaulan bebas pun banyak terjadi. Banyak umat yang terbatas pendidikan formalnya sangat dikuasai oleh teknologi medsos tanpa kemampuan yang memadai untuk mengolah berita. Banyak pemuda, anak-anak bahkan orang dewasa mengasikkan diri dengan 'video game' dari pada terlibat dalam kegiatankegiatan rohani. Namun, ada pula fenomen yang positif. Sebagian umat Katolik punya komitmen yang kuat untuk terus memupuk persaudaraan gerejani dan kerasulan umat. Mereka tekun bekerjasama membangun solidaritas di antara umat. Berbagai aksi sosial dilakukan untuk membantu sesama yang berkekurangan dan berekonomi lemah. Kunjungan-kunjungan dan perhatian terhadap orang-orang tua-jompo dan orang sakit tekun dijalankan. Peribadatan mingguan dan kategorial sebagai 'nafas' kehidupan menggereja dihayati. Kebanyakan pemimpin-pemimpin umat dengan tekun berusaha menggembalai umat lingkungan dan kelompoknya dengan penuh dedikasi dan cinta kasih. Di bawah pimpinan RD. Kaytanus Un 
perjuangan untuk menghadirkan karya pelayanan gerejawi yang bervisi mandiri dan setia kawan terus digalakkan. Visi ini membantu membimbing umat untuk menghayati ketaatan kepada Tuhan yang penuh kasih dengan hukum-hukumnya yang menghidupkan. Upaya 'pendisiplinan' umat melalui hidup berliturgi yang baik dan benar digalakkan. Ketaatan berliturgi dan keterlibatan aktif dalam kegiatankegiatan rohani, membantu umat untuk semakin bertumbuh dan berkembang dalam menghayati nilai-nilai Injili dalam kehidupan pribadi, keluarga dan kehidupan bermasyarakat.

\section{b. Suara-suara emas St. Petrus dan Paulus Oesapa}

Inilah suara-suara emas dari enam tokoh Gereja Katolik Oesapa untuk menghadirkan realita dan perjuangan dalam menghantar umat kepada pengenalan akan kasih Tuhan dan ketaatan kepada hukum-hukumNya.

Pastor bakal Paroki Oesapa, RD. Kaytanus Tan Un (40 tahun)

"Di saat awal pemekaran Gereja St. Petrus dan Paulus Oesapa menjadi Bakal Paroki, jumlah umat Katolik terorganisir dalam 8 KUB. Kemudian demi pendekatan pelayanan kepada umat, maka dimekarkan menjadi 13 KUB dan 5 Wilayah. Maksud utama pemekaranpemekaran KUB adalah agar umat semakin terlibat aktif dan bertanggungjawab dalam kegiatan dan aktivitas hidup menggereja. Selanjutnya, keadaan dari cukup banyak umat Katolik di Bakal Paroki Oesapa yang hidup dalam pola kos-kosan dan kontrakan dan dengan demikian berpindah-pindah, membutuhkan perhatian yang lebih intensif dari kami para pelayan umat.
Dampak dari hidup berpindah-pindah adalah berkurangnya perhatian umat terhadap kehidupan rohani dan imannya. Maka untuk menjawabi situasi ini, salah satu strategi yang dibuat adalah dengan memperbaiki tata kelola berliturgi, misalnya dengan pengaktifan koor-koor Gereja di setiap lingkungan sehingga pemuda-pemudi khususnya dapat turut serta berliturgi secara aktif. Hidup berliturgi menjadi fokus saya selain pembangunan gedung Gereja dan pembinaan iman umat. Pembangunan gedung Gereja sedang diusahakan karena masih banyak umat yang mengikuti misa di Paroki-Paroki lain. Kendalanya adalah belum adanya lokasi yang memadai. Tetapi ingin saya tandaskan lagi bahwa strategi pemekaran KUB telah mulai menampakkan perubahan-perubahan dalam keterlibatan hidup menggereja. Saya melihat bahwa kesadaran orang muda untuk mengikuti perayaan ekaristi dari tahun ke tahun semakin meningkat. Juga pemahaman tentang Kitab Suci dan penghayatan ajarannya semakin membaik pula. Hanya perlu diakui bahwa banyak keluarga Katolik yang belum memiliki Kitab Suci atau Alkitab. Tentang gedung Gereja yang baru kami terus mengusahakannya. Akan tetapi megahnya gedung Gereja bukanlah jaminan bagi kuatnya iman umat. Kebersamaan, kerjasama dan komunikasi yang baik antar pemimpin umat dengan umat dan umat dengan umat adalah kunci keberhasilan hidup menggereja”.

Wakil ketua Dewan bakal Paroki Oesapa, Bapak Emanuel Tefa (60 tahun)

"Banyak umat di wilayah Gereja ini tidak berdomisili secara tetap karena kebanyakan mahasiswa. Berkaitan dengan pembangunan gereja, masih ada kendala dengan tanah atau lokasi 
pembangunan yang sempit. Untuk mengaktifkan umat, biasanya saat Natal dan Paskah, umat yang berkecukupan membantu umat yang berkekurangan. Ada bantuan-bantuan sosial-ekonomi. Lalu dulu perayaan misa hanya sekali saja karena banyak umat yang tidak aktif. Sekarang ini perayaan misa sudah dua kali, pagi dan sore, dan umat banyak sekali. Penggunaan Kitab Suci dalam katakese pun dilakukan.

Bapak Darius Kora (55 tahun): Sekretaris Kuasi Paroki

"Hambatan yang ada yakni dulunya susah mengatur umat tetapi sekarang umat sudah mulai terlibat. Dulu anakanak muda tidak tahu memimpin doa tetapi sekarang mereka sudah tahu cara memimpin doa. Umat sekarang sudah aktif misa baik pagi maupun sore hari. Ini semua bukti dari upaya pemimpin Gereja merangkul umat yang tidak aktif. Pemahaman KS: dulu banyak umat yang tidak punya Kitab Suci dan tidak semua umat melibatkan diri dalam kegiatan katekese. Namun sekarang sudah ada perkembangan. Di sini sering diadakan lomba baca Kitab Suci dan pada tahun ini dari Gereja ini meraih juara III dalam lomba Mazmur Pesparani. Kitab Suci pun mulai dihidupi".

Bapak Petrus Hansi (60 tahun): Ketua Wilayah

"Sebenarnya kekuatan yang dimiliki oleh Gereja ini adalah orang muda. Namun perkembangan teknologi tidak ditanggapi dengan sikap selektif oleh kaum muda sehingga mempengaruhi mental anak muda. Mereka tidak peduli dengan misa dan kegiatan rohani. Memang dulunya OMK kurang aktif, namun sekarang OMK sudah mulai aktif berpartisipasi dalam kegiatan-kegiatan rohani. Setiap kali Natal dan Paskah ada pembagian sembako untuk umat atau Panti Asuhan. Rencana ke depan diupayakan bantuan dana pendidikan bagi anak-anak yang tidak mampu namun punya niat untuk bersekolah".

Bapak Yakobus Tefa (50 tahun): Ketua KUB

"Kehidupan rohani umat baik walaupun kehidupan ekonomi moratmarit. Pastor Gereja punya peranan besar dalam membangkitkan kehidupan iman umat terutama keaktifan dalam kegiatankegiatan gerejawi”.

Bapak Bruno Aru (60 tahun): Tokoh Umat

"Dengan adanya Rm. Tan Un, Pr. yang bertugas sebagai Pastor Kuasi Paroki ini, Liturgi semakin ditata dengan lebih baik. Pembangunan gedung Gereja yang belum terealisir yang menjadi kendala mengapa sebagian umat lebih suka mencari Gereja lain untuk misa. Gerakan Seribu Rupiah sebagai salah satu upaya untuk pembangunan gedung Gereja tersendat, karena belum ada bangunan Gereja. Banyak anak muda yang keluar dari Gereja Katolik dan pindah agama karena mengikuti pasangan mereka yang berbeda agama. Ada umat yang hanya mengikuti misa ketika tiba hari raya Natal dan Paskah. Ada juga misa pemberkatan nikah dilakukan di paroki lain karena saranaprasarana tidak memadai (bangunan gereja). Belum ada pemahaman baik tentang katekese atau syering Kitab Suci”. 


\section{Analisis data: Kelemahan yang mengundang dan kekuatan yang menjanjikan}

\section{a. Kelemahan}

Kelemahan utama yang ada di antara umat Bakal Paroki Oesapa ialah terdapatnya 'keterbatasan ekonomi' pada sebagian besar umat Oesapa dan adanya pola hidup 'sementara' (berpindahpindah), karena hidup di kos-kosan dan kontrakan. Banyak umat bekerja sebagai pedagang kaki lima, nelayan, tukang dan karyawan/i toko dan buruh kasar. Keadaan kerja yang demikian memberi 'kesulitan' dalam keterlibatan berkegiatan rohani baik di tingkat KUB mapun di tingkat Wilayah dan Paroki. Pekerjaan mereka menyita waktu mereka untuk ke Gereja.

Komposisi umat yang didominasi oleh dunia mahasiswa membawa 'kesulitan' tersendiri bagi Gereja. Dari 1700-an umat Katolik Bakal Paroki Oesapa, ada 900-an yang berstatus mahasiswa. Jadi lebih dari setengah umat Katolik Oesapa, itu mahasiswa. Dan kebanyakan mereka menempati rumah kos-kosan dan kontrakan untuk jangka waktu tertentu, terbatas. Sifat 'kesementaraan' dari domisili para mahasiswa ini menjadikan Gereja Oesapa semacam Gereja 'nomaden' atau Gereja 'ziarah'. Kebanyakan mahasiswa beralasan tidak bisa terlibat dalam kegiatan gerejani karena adanya beban kuliah dan kegiatan kampus. Mungkin juga karena adanya kesulitan ekonomi. Selain itu, ada juga fenomen lain di kalangan anak muda termasuk para mahasiswa, yakni tersitanya banyak waktu mereka untuk 'video game online'. 'Kotbah' dunia maya lebih mengasikkan mereka, tetapi juga 'mengubur' mereka.

Kelemahan dan keterbatasan di atas menjadikan banyak umat Oesapa tidak memiliki visi iman yang kuat. Umat lebih berusaha mengejar hal-hal material dan duniawi, dan melalaikan serta mengabaikan kehidupan rohani dan kehidupan gerejani yang sesungguhnya merupakan energi dan jiwa dari kehidupan manusia yang intens dengan umat untuk mendengarkan keluhan tentang apa yang dibutuhkan sehingga umat dapat bertumbuh dalam kasih dan melibatkan diri dalam tugas-tugas gereja. Sebaliknya dalam diri umat (orang dewasa dan OMK yang tidak aktif) hendaknya mempunyai keterbukaan untuk menerima dorongan positif dari pihak Gereja entah melalui himbauan, nasehat, pewartaan agar terlibat dalam kehidupan menggereja. Hanya dengan demikian umat dapat bersama-sama menjadi pengikut Kristus yang mampu menumbuhkembangkan imannya serta menghayati kesetiaannya pada Tuhan dan hukum-hukumnya. Pada akhirnya umat dapat mengalami sukacita iman sebagaimana diamanatkan dalam Mazmur 128: "Berbahagialah setiap orang yang takut akan Tuhan, yang hidup menurut jalan yang ditunjukkanNya" (ay. 1); dan "Sesungguhnya demikianlah akan diberkati orang yang takut akan Tuhan" (ay. 4).

\section{b. Kekuatan}

Di balik kelemahan dan keterbatasan, ada pula beberapa kelebihan umat yang menjadi kekuatan dari Gereja St. Petrus dan Paulus Oesapa.

Pertama, Adanya Visi dan Kepemimpinan Gereja Katolik yang kuat dan berwibawa. Gereja Katolik di mana saja berada mendasarkan kepemimpinannya pada kepemimpinan Imam Agung Yesus Kristus, yaitu kepemimpinan yang melayani, berkorban dan memberikan seluruh jiwa ragaNya 
bagi keselamatan manusia. Visi ini pula yang dimiliki dan dihayati oleh 'management' Bakal Paroki Oesapa. Imam dan pemimpin-pemimpin awam di Bakal Paroki ini dengan tekun beribadat dan berpastoral menjadi teladan dan motivasi bagi umat. Kerjasama yang kuat di kalangan pemimpin umat Oesapa ini menjadi embrio kerjasama dari seluruh umat sebagai satu Gereja. Perangkatperangkat kepemimpinan dalam KUB, Wilayah, Stasi, Bakal Paroki menjadi kekuatan struktural gerejani dari Bakal Paroki ini. Kerohanian dan pastoral dari para pemimpin umat di St. Petrus dan Paulus Oesapa merupakan energi dan kekuatan utama dari seluruh dinamika kehidupan menggereja di Bakal Paroki ini.

Kedua, Besarnya Kepedulian Sosial dari sebagian umat yang berkecukupan terhadap yang berkekurangan. Bahkan umat yang berkekurangan pun bersedia memberi dari keterbatasannya. Secara rutin terjadi di Bakal Paroki ini adanya kegiatan pembagian sembako kepada keluarga-keluarga tak dan kurang mampu khususnya di hari raya Natal dan Paskah. Sikap kepedulian ini pun ditampakkan dalam kerelaan untuk secara tetap menyumbang dan menderma demi dibangunnya nanti gedung gereja yang baru. Kepedulian sosial yang dimiliki oleh sebagian umat Oesapa menunjukkan adanya sikap tanggung jawab umat terhadap kehidupan dan martabat manusia. Semua ini mewujudkan ajaran dan nilai cinta kasih Kristiani di dalam kehidupan bersama dan bermasyarakat.

Ketiga, Adanya Pertobatan, yaitu pertumbuhan dan perkembangan iman umat dalam mencintai Tuhan dan Gereja. Berdasarkan jawaban para responden ditemukan bahwa ada perkembangan dalam hal keterlibatan atau partisipasi umat dalam kegiatan-kegiatan Gereja. Banyak umat dewasa dan kaum muda yang dulunya tidak peduli dengan kegiatan-kegiatan Gereja kini sudah aktif terlibat dalam kegiatan-kegiatan tersebut. Khususnya OMK yang dulunya jarang misa dan tidak bisa memimpin, sekarang sudah aktif misa serta bisa memimpin doa khususnya dalam kegiatan katekese/sharing Kitab Suci dan doa rosario.

\section{Strategi pastoral dalam menghidupi iman umat bakal Paroki St. Petrus dan Paulus Oesapa}

\section{a. Strategi 'Raja'}

Romo Tan Un bersama perangkat kepemimpinan Bakal Paroki Oesapa menerapkan pola kepemimpinan 'Tuhan sebagai Raja' (Mzm 93) dalam mengayomi umat Oesapa. Mereka sangat memperhatikan kebenaran dan kebaikan peribadatan suci, khususnya kekhidmatan misa kudus sebagai 'darah dan jantung' dari kehidupan kristiani. Romo Tan sebagai imam mengembangkan satu pola berliturgi yang 'partisipatif' dan 'involving' sehingga liturgi menjadi lebih hidup dan 'memprovokasi' umat untuk kuat dan erat bersatu secara sakramental dengan Tuhan dan Allah. Kotbah Romo yang teologis-anthropologis serta terukur dan menggugah menghantar umat kepada kebenaran dan kebaikan Injili yang bermanfaat bagi keselamatan jiwa dan raga umat. Romo Tan menjadikan liturgi, khususnya misa kudus sebagai 'Bait Suci": "Beribadahlah kepada TUHAN dengan sukacita, datanglah ke hadapanNya dengan sorak-sorai. Masuklah melalui pintu gerbangNya dengan nyanyian syukur, ke dalam pelataranNya dengan puji-pujian, bersyukurlah kepadaNya dan pujilah namaNya. Sebab TUHAN itu baik, kasih 
setiaNya untuk selama-lamanya, dan kesetiaanNya tetap turun-temurun" (Mzm 100:2.4-5). Dan sekarang di Oesapa, misa Hari Minggu dan Hari Raya sangat kelimpahan dihadiri oleh umat. Dua kali misa tidak mampu lagi menampung umat, sehingga memang sangat diperlukan sebuah bangunan gereja baru yang memadai. Selanjutnya, pemimpin-pemimpin awam Gereja Oesapa juga sangat memperhatikan kebenaran dan kekhusukan liturgi di dalam KUB dan Wilayah Gerejani. Mereka memimpin kelompok-kelompok umat dalam doa dan pembacaan Firman Tuhan. Tetapi mereka dan Romo Tan juga menghayati dan mengayomi umat dengan pola kepemimpinan Tuhan sebagai Raja. Mereka menghayati satu kepemimpinan yang sungguh bertanggung jawab dan penuh penyerahan diri. Mereka memotivasi umat dengan kegiatan-kegiatan Perlombaan Baca Kitab Suci, Pendarasan Mazmur dan Perlombaan Paduan Suara Gerejani. Mereka pernah menjadi Juara III Perlombaan Baca Mazmur pada Pesparani Tingkat Kota Kupang tahun 2019. Peneliti utama, RD. Valens Boy yang biasa membantu merayakan misa kudus di Oesapa menemukan selalu kesiagaan dan ketelitian prima dari Romo Tan dan para petugas liturgi dalam melayani umat Allah.

Pola kepemimpinan "Raja" juga dihadirkan oleh Romo Tan dan para pemimpin awam di sana dengan mengaplikasikan management back to base. Basis Gereja adalah umat Allah, dan karena itu harus 'kembali ke umat'. Demi pendekatan pelayanan dan kasih yang menjangkau yang 'jauh', Romo Tan memekarkan KUB. Yang semula hanya 8 KUB kini dimekarkan menjadi 15 KUB. Penggandaan yang menghidupkan.
Tujuannya, semata untuk keselamatan jiwa dan kesejahteran hidup umat Allah, sebagaimana didaraskan Mazmur 128: "Istrimu akan menjadi seperti pohon anggur yang subur di dalam rumahmu; anak-anakmu seperti tunas pohon zaitun sekeliling mejamu" (Mzm 128:3).

\section{b. Strategi 'Pengharapan'}

Para pemimpin umat dan sebagian umat Bakal Paroki Oesapa selalu membawa pengharapan bagi sesama, khususnya bagi mereka yang menderita dan berkekurangan. Perhatian, kasih sayang dan pertolongan mereka terhadap yang lemah, yang miskin dan yang berkekurangan itu bagaikan restorasi kehidupan umat Israel dari pembuangan di Babel. Mereka membawa 'pengharapan di tengah-tengah penderitaan' (Mzm 126) dan dengan demikian menumbuhkan dan membangun pengharapan bagi suatu masa depan yang lebih baik. Sesama umat Allah Oesapa yang dibantu, ditolong, didoakan, dikunjungi dan dilayani menemukan kebenaran ini: "Ketika TUHAN memulihkan keadaan Sion, keadaan kita seperti orang-orang bermimpi. Pada waktu itu mulut kita penuh dengan tertawa, dan lidah kita dengan sorak-sorai. TUHAN telah melakukan perbuatan besar kepada kita, maka kita bersukacita" (Mzm 126:1-3). Melalui kegiatan-kegiatan amal dan sosial dari umat Oesapa dengan pemberian bantuan ekonomi kepada orang-orang tua, janda dan keluargakeluarga miskin, dan juga kunjungankunjungan doa kepada mereka yang sakit dan menderita, umat Oesapa terus membawa pengharapan bagi sesama yang 'menderita'. 


\section{c. Strategi 'Berjaga'}

Romo Tan bersama para pemimpin umat Oesapa menganut pula spiritualitas Mazmur 121: 'TUHAN, Penjaga Israel', yaitu "Ia takkan membiarkan kakimu goyah, Penjagamu tidak akan terlelap" (ay.3). Mereka selalu memelihara persaudaraan dan kerukunan umat Allah. Dengan berkatakese, berkotbah, bersatu dengan umat tua-muda, besar-kecil dalam suka dan duka, mereka menghantar umat untuk tetap 'menjaga' kewibawaan kasih setia Tuhan dan hukum-hukumNya. Melalui katakese, khususnya para mahasiswa dan sebagian umat yang dikuasi oleh 'video game online' dan pola hidup bebas menemukan kembali jalan yang benar dan membahagiakan.

\section{Kesimpulan}

Mazmur-Mazmur ini dengan tematemanya yang menjadi landasan teoritis penelitian kami, yaitu 'TUHAN adalah Raja yang kekal' (93), 'TUHAN terpuji di BaitNya yang Suci' (100), 'TUHAN adalah Penjaga Israel' (121), 'TUHAN adalah Pengharapan di tengah-tengah Penderitaan'(126), dan 'TUHAN adalah Pemberi Berkat', sesungguhnya mengemban satu pesan tunggal bahwa Tuhan, Allah Israel itu adalah Allah yang penuh kasih setiaNya, dan karena itu umatNya perlu dan wajib mentaati hukum-hukumNya.

Berdasarkan kebenaran dan spiritualitas kelima Mazmur sebagai landasan teoritis, kami telah melakukan Penelitian di Bakal Paroki St. Petrus dan Paulus Oesapa dalam rangka untuk mengetahui dan memahami sejauh mana kasih setia Tuhan meresapi kehidupan beriman umat kristiani dan pemimpinpemimpinnya, dan bagaimana umat menghayati kasih setia Tuhan dengan mentaati hukum dan ketetapanNya juga secara Gerejani Katolik?

Hasil Penelitan kami menemukan bahwa umat Oesapa dan pemimpinpemimpinnya terus berdinamika kuat untuk mengamalkan kasih setia Tuhan di dalam kehidupan menggereja. Dengan tekun mereka terus berjuang dalam rahmat Tuhan untuk mentaati hukum dan ketetapan Tuhan sebagai 'jalan, kebenaran dan hidup'. Dan 'jalan, kebenaran, dan hidup' yang mereka amalkan demi perestorasian hidup dan perolehan berkat Tuhan adalah penghayatan hidup akan Tuhan sebagai 'Raja, Pengharapan, dan Pemberi Berkat"!

\section{Daftar Pustaka}

Alkitab, Lembaga Alkitab Indonesia, Jakarta, 2006

Alkitab Deuterokanonika, Lembaga Alkitab Indonesia, Jakarta, 2007.

ALKITAB Edisi Studi, Lembaga Alkitab Indonesia, Jakarta, 2011.

Christian Community Bible, Catholic Pastoral Edition, Philippines, Quaezon City, 1990.

Elliger, K., \& W. Rudolph, Biblia Hebraica Stuttgartensia, Germany: Gesamtherstellung Biblia-Druck Stuttgart, 1990.

Perjanjian Lama Ibrani-Indonesia, Lembaga Alkitab Indonesia, Jakarta, 2016.

Konsili Vatikan II, Dei Verbum, Konstitusi Dogmatis tentang Wahyu Ilahi (21 November 1964), dalam R. Hardawirjana (Penerj.), Dokumen Konsili Vatikan II, Jakarta: Obor, 1993. 
Paus Yohanes Paulus II, Anjuran Apostolik Familiaris Consortio tentang Peranan Keluarga Kristen dalam Dunia Modern (22 November 1981), dalam R. Hardawirjana (Penerj.), Seri Dokumen Gerejawi no. 30, Jakarta: Dokpen KWI, 2011. ,(Promulgator),

Katekismus Gereja Katolik, terjemahan Indonesia oleh $\mathrm{P}$. Herman Embuiru, SVD, Ende: Propinsi Gerejani Ende, 1995.

Browning, W. R. F., Kamus Alkitab, Jakarta: PT BPK Gunung Mulia, 2010.

Douglas, J.D dkk (eds.), Ensiklopedi Alkitab Masa Kini; Jilid II M-Z, Jakarta: Yayasan Komunikasi Bina Kasih/OMF, 2002.

Freedman, David Noel, The Anchor Bible Dictionary, New York: Doubleday Publishing, 1992.

George Arthur Buttrick, Cs (eds.), The Interpreter's Dictionary of the Bible; An Illustrated Encyclopedia, Nashville: Abingdon Press, 1990.

Walker, D.F., Konkordansi Alkitab, Jakarta: BPK. Gunung Mulia, 2009.

Barth, C., Theologia Perjanjian Lama, Jakarta: BPK Gunung Mulia, 2009.

Barth, Christoph dan Marie Claire Barth Frommel, Teologi Perjanjian Lama 1, Jakarta: BPK Gunung Mulia, 2013.

Bergant, Dianne, CSA dan Robert J. Karris, OFM, Tafsir Alkitab Perjanjian Lama, Jakarta: Lembaga Biblika Indonesia, 2002.

Bullock, C., Hassel, Kitab-Kitab Puisi Dalam Perjanjian Lama, Malang: Gandum Mas, 2003.

Claire Barth, Marie dan B. A. Pareira, Kitab Mazmur 1-72: Pembimbing dan Tafsirannya, Jakarta: BPK Gunung Mulia, 2005.
Tafsiran Alkitab: Kitab Mazmur 73-150, Jakarta: PT BPK. Gunung Mulia, 2013.

Craven, Toni, The Book of Psalms, Message of Biblical Spirituality 6, Collegeville, Minnesota: The Liturgical Press, 1992.

Darmawijaya St, Jiwa Dan Semangat Perjanjian Lama 3; Pesan Para Bijak Bestari, Yogyakarta: Kanisius, 1992.

Elia, Poppy Mary, Obrolan Hikmat, Jakarta: BPK Gunung Mulia, 2011.

Eminyan, Maurice, Teologi Keluarga, Yogyakarta: Kanisius, 2001.

Groenen, C., Pengantar ke dalam Perjanjian Lama, Yogyakarta: Kanisius, 1992.

Haight, Roger, Jesus Symbol of God, Maryknoll: Orbis Books, 1999.

Henry, Matthew, Tafsiran Matthew Henry: Kitab Mazmur 101-150, Surabaya: Momentum, 2012.

Holladay, L., William, A Concise Hebrew and Aramic Lexicon of the Old Testament, Leiden: E.J Brill Publishing, 1989.

Midali, Mario, Spiritualita Apostolica; Personali e Vitali Riferimenti Fondanti, Roma: Liberia Ateneo Salesiano, 1994.

Schaeter O. S. B, Konrad, Berit Olam Studies In Hebrew Narrative and Poetry Psalms, Collegeville Minnesota: Amichael Glazier Book The Liturgical Press, 2001.

Schokel, L. Alonso dan Cecilia Carniti, I SALMI: Volume Primera, Roma: Della Fornanci, 1993. I SALMI:

Volume Secundo, Roma: Della Fornanci, 1993. 
Wright, Christopher, Hidup sebagai Umat Allah Etika Perjanjian Lama, Jakarta: Gunung Mulia, 2003.

Boy, Mikhael Valens, Eksegese Mazmur (Modul), Kupang: FF-UNIKA Widya Mandira, 2007.

\section{Lampiran}

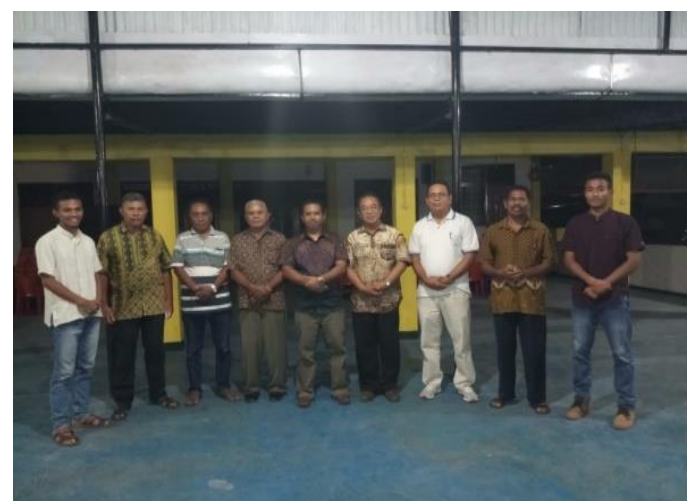

Foto: Peneliti-Utama, Peneliti-Mahasiswa, dan 6 Orang Responden

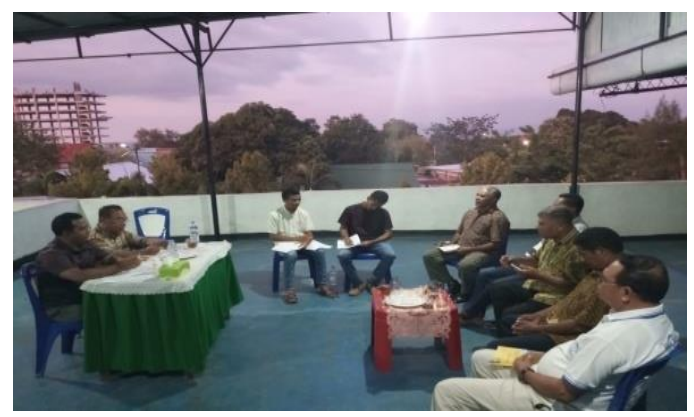

Foto: Suasana Wawancara 